\title{
DIRECTIONS OF BREEDING OF GRAIN SORGHUM IN THE LOWER VOLGA REGION OF RUSSIA
}

\author{
Kibalnik Oksana*, Semin Dmitry, Gorbunov Vyacheslav, \\ Zhuzhukin Valery, Efremova Irina, Kukoleva Svetlana, \\ Starchak Victoria, Arhipov Aleksey, Kameneva Olga
}

Federal State Budgetary Scientific Institution Russian Research and Design Institute of sorghum and corn "Rossorgo", Russia

\section{НАПРАВЛЕНИЯ СЕЛЕКЦИИ ЗЕРНОВОГО СОРГО В НИЖНЕВОЛЖСКОМ РЕГИОНЕ РОССИИ}

\author{
Кибальник Оксана, Семин Дмитрий, Горбунов Вячеслав, \\ Жужукин Валерий, Ефремова Ирина, Куколева Светлана, \\ Старчак Виктория, Архипов Алексей, Каменева Ольга
}

Received 26. 6. 2017

Revised 28. 6. 2017

Published 27. 11. 2017

Sorghum bicolor L. Moench is a versatile crop, corn which is used for forage and fodder (for feeding agricultural animals, birds, fishes), as well as a source of raw materials for the food processing industry. Especially important is the cultivation of sorghum in the lower Volga region of Russia, characterized by frequent soil and air droughts. In "Rossorgo" scouting for earliness, high yield, improved grain quality, resistance to diseases and pests. The test sorghum genotypes were conducted at the experimental field of center "Rossorgo" in 2014-2016. All records of productivity elements of productivity and biochemical evaluation of grains are made according to standard techniques. The results of long-term work were identified and approved for use in the lower Volga region 12 varieties and 2 hybrids of sorghum. Varieties Pischevoe 35, Pischevoe 614, Kremovoe, Fakel can be used in the food industry. Grits from grain of sorghum has a higher ratio of the cooking property in comparison with cereals from other cultures. The early-maturing varieties Perspektivny 1 and Start, intended for planting with different width of spacing 15, 45 and $70 \mathrm{~cm}$ were bred. Varieties of Granat, Volzhskoe 44, Avans and hybrids Irgiz, Volgar, combine high yields (5.31-10.8 t/ha) and 11.32-12.56\% of crude protein in grain. Heterotic hybrids of Irgiz and Volgar are by tall $(149.6$ of $175.9 \mathrm{~cm})$ and highest grain yield $(8.02-10.8 \mathrm{t} / \mathrm{ha})$. As raw material for starch varieties recommended Avans, Volzhskoe 44, Sarmat, Perspektivny 1, Geliofor, Volzhskoe 4, Topaz and hybrid Volgar with content in grain starch $72.31-75.60 \%$. New varieties (Azart, Geliofor, Magistr, Bogdan, Bakalavr, Granat) characterized by a high content of starch $(71.47-74.50 \%)$ and medium protein (the 11.04-12.59\%), pass state testing. Thus, "Rossorgo" offers a farmer a range of cultivars and hybrids of grain sorghum, allowing the obtaining stable yields of grain and extending the use of culture in the region.

Keywords: sorghum; breeding; yield; directions for use; maturity; protein; starch

*Corresponding author: Oksana Kibalnik, Federal State Budgetary Scientific Institution Russian Research and Design Institute of sorghum and corn "Rossorgo", Russia, $\triangle$ kibalnik79@yandex.ru 


\section{Введение}

Зерновое сорго является одной из наиболее засухо- и жароустойчивых, высокоурожайных сельскохозяйственных культур, которая возделывается во многих регионах мира с острозасушливым климатом. Сорго используют в основном для производства зернофуража и монокорма (Алабушев и др., 2003), а также в пищевой и перерабатывающей промышленности (Ковтунов и Горпиниченко, 2011; Никитин и др., 2016).

Селекционная работа с сорго в России началась в начале 20 века с районов Северного Кавказа (Алабушев и др., 2017). Высокая питательная ценность зерна сорго (12 - 14 \% белка, 70 - 80 \% крахмала и т.д.) способствовали его интродукции в более северные регионы страны. Так, в 1973 г. была образована лаборатория генетики и селекции сорговых культур при Саратовском сельскохозяйственном институте, на базе которой сформирован ФГБНУ РосНИИСК «Россорго» (2003 г.). Одним из направлений деятельности института является выведение новых скороспелых, высокоурожайных сортов и гибридов сорго с улучшенным качеством зерна, стабильно вызревающих и позволяющих организовать промышленное семеноводство в условиях Нижневолжского региона России (Горбунов, 2016).

\section{Материалы и методы}

Объектами исследований являются 18 сортов и 2 гибрида сорго (разного направления использования), которые высевали на опытном поле ФГБНУ РосНИИСК «Россорго» в 2014 2016 гг. широкорядным способом (с междурядьем 70 см). Густота стояния - 100 тыс. раст./га. Площадь делянки $25 \mathrm{~m}^{2}$, размещение рендомизированное, повторность трехкратная. Все учеты урожайности зерна, элементов продуктивности выполнены согласно общепринятой методике (1989). Определение биохимического состава зерна проводилось в лаборатории биотехнологии ФГБНУ РосНИИСК «Россорго» (Ермаков, 1987). Экспериментальные данные обработаны дисперсионным анализом с помощью программы Агрос 2.09.

\section{Результаты и их обсуждение}

Селекционная работа проводится в нескольких направлениях: скороспелость, высокая урожайность, устойчивость к болезням и вредителям, применение в пищевой и перерабатывающей промышленности. В результате применения метода межсортовой гибридизации с последующим отбором создан генетически разнообразный исходный материал, на основе которого выведены и допущены к использованию по Нижневолжскому региону 12 сортов, различающихся по продолжительности вегетационного периода, урожайности и биохимическому составу зерна. Развивается гетерозисная селекция: на основе ЦМС типа А2 получены гибриды Иргиз и Волгарь, характеризующиеся высоким гетерозисом по продуктивности. Проходят государственное сортоиспытание 6 сортов: Азарт, Гелеофор, Магистр, Богдан, Бакалавр, Гранат.

Сорта селекции «Россорго» представлены тремя группами спелости: раннеспелые, среднеранние и среднеспелые. Для получения сортов зернофуражного направления основное внимание уделяется высокой и стабильной урожайности. Также с целью повышения питательности концентрированного корма необходимы сорта с высоким содержанием в зерне протеина. В институте «Россорго» селекционерами решается эта проблема: сельхозпроизводителям представлены сорта Гранат, Волжское 44, Аванс и гибриды Иргиз, Волгарь, сочетающие высокую урожайность 5,31 - 10,8 т/га и 11,32 - 12,56 \% в зерне сырого протеина (табл. 1).

В настоящее время технология возделывания зернового сорго ориентирована на использование семян сортов, отвечающих требованиям ресурсосберегающей технологии. В связи с чем, развивается направление селекции тонкостебельного сорго, толерантного к загущению посевов (Семин и др., 2016). Такие линии были получены в результате скрещивания 
зернового сорго с суданской травой и получили название - судзерны. На их основе выведены сорта Перспективный 1 и Старт.

Таблица 1 Характеристика сортов зернового сорго по основным агрономическим признакам (2014 - 2016 гг.)

Table 1 Characteristic of grain sorghum varieties by the main agronomic features (2014-2016)

\begin{tabular}{|c|c|c|c|c|c|c|c|}
\hline \multirow[t]{2}{*}{ Сорт, гибрид } & \multirow{2}{*}{ 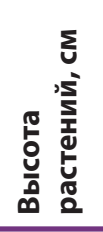 } & \multirow[b]{2}{*}{ 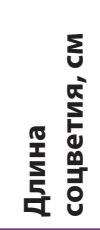 } & \multirow[b]{2}{*}{ 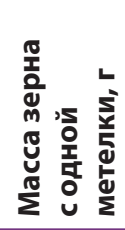 } & \multirow[b]{2}{*}{ 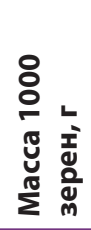 } & \multirow{2}{*}{ 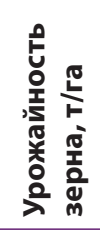 } & \multicolumn{2}{|c|}{ Содержание в зерне, \% } \\
\hline & & & & & & 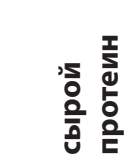 & $\begin{array}{l}5 \\
\sum_{x}^{0} \\
\frac{\pi}{\pi} \\
\frac{0}{y}\end{array}$ \\
\hline \multicolumn{8}{|c|}{ Раннеспелые } \\
\hline Перспективный 1 & 110,3 & 14,1 & 3,0 & 29,0 & 3,24 & 13,71 & 72,99 \\
\hline Старт & 126,8 & 23,7 & 9,5 & 28,5 & 4,05 & 13,54 & 67,96 \\
\hline Toпаз & 125,3 & 22,0 & 12,3 & 27,1 & 3,88 & 11,23 & 75,60 \\
\hline Факел & 145,9 & 26,6 & 16,7 & 30,1 & 5,27 & 12,48 & 73,73 \\
\hline Аванс & 119,2 & 25,9 & 21,9 & 37,4 & 5,84 & 12,56 & 72,31 \\
\hline \multicolumn{8}{|c|}{ Среднеранние } \\
\hline Волжское 615 & 137,1 & 25,4 & 13,2 & 29,9 & 4,33 & 12,10 & 69,01 \\
\hline Азарт & 122,5 & 20,7 & 12,2 & 36,7 & 4,97 & 12,59 & 72,52 \\
\hline Гелеофор & 125,7 & 22,0 & 19,7 & 30,6 & 4,92 & 11,04 & 74,50 \\
\hline F1 Волгарь & 175,9 & 25,5 & 35,8 & 29,9 & 10,8 & 11,32 & 73,29 \\
\hline F1 Иргиз & 149,6 & 26,5 & 20,3 & 23,0 & 8,02 & 11,66 & 70,61 \\
\hline \multicolumn{8}{|c|}{ Среднеспелые } \\
\hline Кремовое & 130,1 & 27,7 & 13,8 & 30,1 & 3,96 & 14,30 & 70,69 \\
\hline Пищевое 614 & 119,2 & 24,3 & 11,9 & 24,1 & 3,57 & 12,27 & 68,96 \\
\hline Волжское 4 & 140,6 & 28,6 & 16,6 & 26,7 & 4,76 & 10,57 & 75,06 \\
\hline Волжское 44 & 130,8 & 27,0 & 15,0 & 23,5 & 5,39 & 12,15 & 72,77 \\
\hline Пищевое 35 & 149,7 & 24,1 & 13,6 & 25,2 & 3,70 & 12,90 & 73,97 \\
\hline Гранат & 114,5 & 23,2 & 12,7 & 32,0 & 5,31 & 11,81 & 71,34 \\
\hline Сармат & 130,3 & 18,7 & 14,9 & 36,9 & 4,56 & 11,54 & 73,02 \\
\hline Магистр & 123,7 & 16,2 & 13,2 & 34,3 & 4,37 & 11,30 & 72,03 \\
\hline Богдан & 127,3 & 26,7 & 25,3 & 30,3 & 4,81 & 11,81 & 72,57 \\
\hline Бакалавр & 137,0 & 23,4 & 28,2 & 40,1 & 4,42 & 11,30 & 71,47 \\
\hline F05 & $4,46^{*}$ & $5,03^{*}$ & $3,08^{*}$ & $2,47^{*}$ & $2,19^{*}$ & 1,26 & 1,04 \\
\hline
\end{tabular}

${ }^{*} p \leq 0,05$ 
Для расширения ассортимента крупяных изделий селекционерами созданы сорта пищевого направления: Пищевое 35, Пищевое 614, Кремовое, Факел. Сорговая крупа используется для приготовления разнообразных блюд в виде различных каш, гарниров, супов, пудингов, хлопьев. Исследования показали, что по вкусовым качествам и консистенции каша из сорго не уступает перловой, кукурузной, пшеничной, гречневой и рисовой.

Преимуществом крупы из сорго является более высокая развариваемость и набухаемость по сравнению с крупами из других культур. Коэффициент развариваемости равен 3,27 (Семин и др., 2017). Мука из сорго не содержит глютена, поэтому хлебобулочные и кондитерские изделия рекомендуются в питании больных гипертонией, целиакией, диабетом (Костина и др., 2012). Изучение хлебопекарных качеств зерна сорго показало, что большим объёмом и лучшей пористостью обладают изделия, испеченные из пшеничной муки в смеси с сорговой в соотношении $90: 10 \%$.

В институте проводится селекционная работа по созданию сортов и гибридов сорго, зерно которых может быть использовано в качестве сырья для крахмалопаточной промышленности. В селекционную программу был включен исходный материал со светлой окраской зерна и содержанием крахмала не менее 70 - 72 \%. В настоящее время выведены сорта, соответствующие данным требованиям: Аванс, Волжское 44, Сармат, Перспективный 1, Гелеофор, Волжское 4, Топаз и гибрид Волгарь. Количество крахмала в зерне варьирует от 72,31 до 75,60 \% в зависимости от сортовых особенностей.

\section{Выводы}

Сельхозпроизводителям представлен ассортимент сортов и гибридов зернового сорго, различающихся по морфологическим признакам и биологическим свойствам, пригодных для возделывания по современным технологиям.

\section{Литература}

Алабушев, А., Анипенко, Л., Гурский, Н., Коломиец, Н., Костылев, П., Мангуш, П., Алабушева, О. 2003. Сорго (селекция, семеноводство, технология, экономика). Ростов на Дону, 368 с.

Алабушев, А., Шишова, Е., Романюкин, А., Ермолина, Г., Горпиниченко, С. 2017. Происхождение сорго и развитие его селекции. Научный журнал КубГАУ, т. 3, № 127, с. 1-14. DOI: 10.21515/1990-4665-127-017

Горбунов, В. 2016. Результаты инновационной деятельности ФГБНУ РосНИИСК «Россорго». Кукуруза и сорго, № 3, с. 3-5.

Ермаков, А. 1987. Методы биохимического исследования растений. Л. 430 с. ISBN (ББК) 28.57

Ковтунов, В., Горпиниченко, С. 2011. Основные направления использования сорго зернового. Зерновое хозяйство России, № 6, с. 28-32.

Костина, Г., Семин, Д., Ефремова, И., Кибальник, О., Пешкова, В. 2012. Селекция зернового сорго на пищевые цели в условиях Нижнего Поволжья. Кукуруза и сорго, № 2, с. 3-6.

Методика государственного сортоиспытания сельскохозяйственных культур. 1985. М., вып. 2, 267c.

Никитин, И., Свечников, А., Зоц, А., Алфимова, А., Татраев, Д., Мириев, М. 2016. Анализ применения зерна сорго и продуктов его переработки в технологии хлебобулочных и мучных кондитерских изделий. Технические науки - от теории к практике, т. 30, № 12, с. 123-129.

Семин, Д., Горбунов, В., Кибальник, О. 2016. Технология возделывания новых сортов зернового сорго. Кукуруза и сорго, № 3, с. 10-13.

Семин, Д., Кибальник, О., Каменева, О., Куколева, С., Старчак, В. 2017. Селекция зернового сорго на пищевые цели в условиях Нижневолжского региона РФ. Таврический вестник аграрной науки, т. 9, № 1, с. 72-78. 